\title{
Electron transfer mediators for PQQ dependent soluble glucose dehydrogenase catalyzed lactose oxidation reaction
}

\author{
Greta Vaitkutè, \\ Irina Bratkovskaja, \\ Vida Časaitè, \\ Jonita Stankevičiūtè, \\ Rolandas Meškys, \\ Lidija Tetianec $^{\star}$ \\ Institute of Biochemistry, \\ Life Sciences Centre, \\ Vilnius University, \\ 7 Sauletekio Avenue, \\ 10223 Vilnius, Lithuania
}

\begin{abstract}
The aim of this work was to investigate the application of artificial electron transfer mediators for the pyrroloquinoline quinone-dependent soluble glucose dehydrogenase (PQQ-sGDH) catalyzed lactose oxidation reaction. 1-(N,N-dimethylamine)4-(4-morpholine)benzene (AMB) and N,N'-dimethyl-4,4'-azopyridinium methyl sulfate (MAZP) were used as mediators. The mediators showed a high reactivity with a reduced form of PQQ-sGDH and were used to determine the PQQ-sGDH catalyzed lactose oxidation parameters at $\mathrm{pH} 7.0$ and $\mathrm{pH}$ 8.0.

The use of MAZP and AMB for the regeneration of the oxidized form of PQQsGDH was investigated by applying the electrochemical oxidation of the mediator. The maximum electroenzymatic lactose bioconversion yield and the biggest average PQQ-sGDH turnover number were reached when the buffer solution $\mathrm{pH}$ was 8.0 and $\mathrm{AMB}$ was used as an electron acceptor, which was oxidized on a carbon fiber electrode of a large surface area.
\end{abstract}

Keywords: electron transfer mediators, PQQ-dependent glucose dehydrogenase, lactose, electroenzymatic conversion

\section{INTRODUCTION}

The current demands of sustainable green methodologies have increased the use of enzymatic technology in industrial processes. Employment of enzymes as biocatalysts offers the benefits of mild reaction conditions, biodegradability and catalytic efficiency [1, 2]. Among the enzymes the application of oxidoreductases in the conversion of organic compounds is very attractive for biocatalysis because of the appropriate catalytic activity and substrate specificity of the enzymes [1 $1-6]$.

Quinoprotein oxidoreductases (QPOs) are known to catalyze the oxidation of a wide range of structurally diverse alcohols, primary amines and carbohydrates [6-8]. Carbohydrate dehydrogenases are most common among these QPOs. QPOs can be distinguished by their localiza-

* Corresponding author. Email: lidija.tetianec@bchi.vu.lt tion, i.e. as a soluble or membrane-bound enzyme. Both soluble and membrane-bound forms of glucose dehydrogenase have been found [ 6 , 9p. Soluble pyrroloquinoline quinone (PQQ)dependent GDH originating from Acinetobacter calcoaceticus (PQQ-sGDH) is a homodimeric enzyme containing one PQQ and three $\mathrm{Ca}^{2+}$ ions per monomer [10]. The enzyme has a broad substrate specificity. GDH catalyzes the oxidation of monosaccharides, such as glucose, xylose and galactose, as well as disaccharides, such as lactose and melibiose. The products of carbohydrate oxidation are the corresponding lactones [9, 11]. GDH acts according to the ping-pong mechanism, and both substrate inhibition by glucose and a negative cooperativity effect have been demonstrated [11]. The structure of the enzyme has been resolved, and the catalytic mechanism of the reductive halfcycle has been elucidated [12, 13, 
Because of a high catalytic activity, insensitivity to atmospheric oxygen and a broad sacharidic substrate specificity PQQ-sGDH can be applied in many fields including construction of biosensors and bioconversion systems [5, 6, 14, 17]. Practical applications of the PQQ-sGDH require an effective enzyme reoxidation process. Oxygen reacts slowly with the reduced enzyme, and the reactivity of organic compounds acting as artificial electron acceptors is in general higher [5, 18]. The high reduced enzyme oxidation rate is an important step for effective enzyme turnover.

Lactose solution in the form of whey is produced in an annual quantity of 145 million tons of which only approximately $60 \%$ is utilized. One of value-added products derived from lactose is lactobionic acid (4-O-b-D-galactopyranosyl-Dgluconic acid). Production of lactobionic acid and its salts and their applications were reviewed in [19, 20]. The growing commercial relevance of lactobionic acid has prompted the development of novel systems for its biotechnological production that are both sustainable and efficient.

In this work we investigated the mediators for the efficient PQQ-sGDH regenerating system during lactose oxidation (Fig. 1). Two mediators - 1-( $N, N$-dimethylamino)-4-(4-morpholynil) benzene (AMB) and N,N'-dimethyl-4,4'-azopyridinium methyl sulfate (MAZP) - were used for the PQQ-sGDH catalyzed lactose oxidation reaction. AMB showed to be an effective electron transfer mediator for the PQQ-sGDH - its bimolecular reactivity with the enzyme constants reaches a value of $4.9 \times 10^{7} \mathrm{M}^{-1} \mathrm{~s}^{-1}$ [ 4 ]. MAZP is a new mediator, but it was shown to be effective in regeneration of an oxidized form of quinohemoprotein alcohol dehydrogenase [21]. Both mediators have a moderate redox potential $(396 \mathrm{mV}$ and $390 \mathrm{mV}$ for MAZP and $A M B$, respectively [22, 23]). In our work we choose the electrochemical oxidation as the method to oxidize the mediator. The electrochemical regeneration of the oxidized mediator form is a convenient method considering the absence of by-products in an enzymatic reactor [24]. Moreover, the reduction of the regeneration scheme to only one biocatalyst increases the preparative value of the biocatalytic synthesis.

\section{EXPERIMENTAL}

\section{Materials}

Recombinant Acinetobacter calcoaceticus PQQdependent GDH (PQQ-sGDH) was purified as described in [25]. The enzyme solution was prepared using deionized water, and the molar concentration was calculated assuming the molecular mass of the enzyme to be $100 \mathrm{kDa}$ [9].

$\mathrm{N}, \mathrm{N}^{\prime}$-dimethyl-4,4'-azopyridinium methyl sulfate (MAZP) and 1-(N,N-dimethylamino)-4-(4morpholynil) benzene (AMB) were synthesized as described previously [22, 23]. Solutions of AMB and MAZP were prepared in methanol and deionized water, respectively. D-(+)-lactose was from Lach-Ner (Czech Republic). Solutions of the lactose were made in deionized water and allowed to mutarotate 1 day before use. All buffer reagents and other chemicals were of analytical grade.

\section{Kinetic measurements and calculations}

The parameters of PQQ-sGDH catalyzed lactose oxidation and of the reactivity of the enzyme with electron transfer mediators were determined by observing the mediator-dependent ferricyanide reduction [26, 27]. In the coupled assay the increase of the rate of low reactive substrate (ferricyanide) reduction is determined by the rate of enzyme

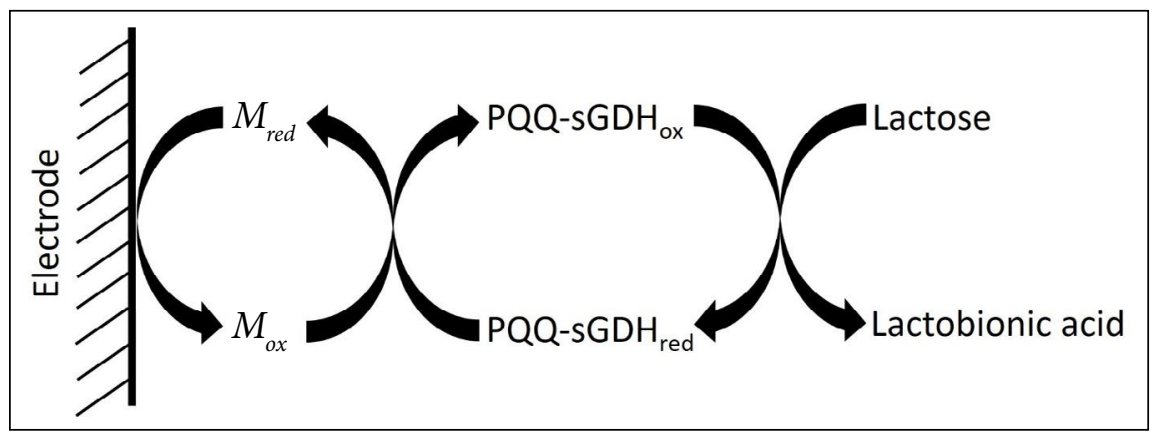

Fig. 1. The scheme of electroenzymatic lactose conversion to lactobionic acid 
interaction with a mediator and a substrate. The oxidation of the mediator with ferricyanide does not limit the process. The reduction of ferricyanide was monitored spectrophotometrically at $420 \mathrm{~nm}$ using a Nicolet evolution 300 spectrophotometer (Thermo Electron Corporation, USA). The concentration of ferricyanide was calculated using its molar extinction coefficient of $1 \mathrm{mM}^{-1} \mathrm{~cm}^{-1}$ [28]. The initial ferricyanide reduction rate was calculated as the slope of ferricyanide concentration change during initial $60 \mathrm{~s}$. To calculate the rate of enzyme catalyzed lactose oxidation the rate of ferricyanide reduction was multiplied by 2 .

The dependence of the initial rate of reaction on the mediator and lactose concentration was analysed by applying the ping-pong enzyme reaction scheme, which included the reversible inhibition of the enzyme with an excess of substrate:

$$
\begin{aligned}
& E_{o x}+S \stackrel{k_{1}}{\leftrightarrow} E S \stackrel{k_{2}}{\rightarrow} E_{\text {red }}+P, \\
& E_{r e d}+M_{o x} \stackrel{k_{3}}{\rightarrow} E_{o x}+M_{r e d}, \\
& E_{r e d}+S \stackrel{K_{i n}}{\leftrightarrow} E_{i n} .
\end{aligned}
$$

Here $E_{o x}$ and $E_{r e d}$ are the oxidized and reduced forms of the PQQ-sGDH, respectively, ES is the enzyme-substrate complex, $E_{\text {in }}$ is the inactive enzyme form, $S$ and $P$ are the substrate and its oxidized product, respectively, $M_{o x}$ and $M_{\text {red }}$ are the oxidized and reduced forms of the mediator, respectively, enzyme catalytic constant $k_{c a t}=k_{2}$, Michaelis constant for substrate $K_{M}=\left(k_{-1}+k_{2}\right) / k_{1}$, bimolecular enzyme and substrate reactivity constant $k_{\text {red }}=k_{1} k_{2} l$ $\left(k_{-1}+k_{2}\right)$, bimolecular enzyme and mediator reactivity constant $k_{o x}=k_{3}$, and the enzyme inhibition with the substrate constant is $K_{i n}$. The ping-pong scheme of enzyme action and inhibition of the quinoproteins by their substrates were demonstrated in previous kinetic studies [5, 18].

Following this scheme (Eqs. 1-3), the dependence of the initial reaction rate on substrate, mediator and enzyme concentrations was expressed:

$$
\begin{aligned}
& v=E_{\text {total }} \cdot \\
& \frac{S \cdot M_{o x} \cdot k_{o x} \cdot k_{c a t}}{M_{o x} \cdot k_{o x} \cdot K_{M}+S \cdot M_{o x} \cdot k_{o x}+S \cdot k_{c a t}+\frac{S^{2} \cdot k_{c a t}}{K_{\text {in }}}} .
\end{aligned}
$$

Here $E_{\text {total }}$ is the total concentration of the enzyme in the reaction mixture. MAZP was considered as two-electron acceptor, and AMB as one-electron acceptor, and to compare these two mediators $2 k_{o x}$ must be used in the analysis of the data for AMB.

All the calculations and the fitting of experimental data to Eq. 4 were performed using the MathCad 2001 software.

\section{Electrochemical measurements}

The cell of electrochemical measurements consisted of two chambers, namely anodic and cathodic chambers, which were interconnected by a bridge of electroconductive agarose gel. Rolled platinum wires (diameter $0.3 \mathrm{~mm}$, length of each unfolded wire approximately $30 \mathrm{~mm}$ ) or carbon fiber thread fixed on a collector of graphite rods were used as working (anode) and auxiliary (cathode) electrodes. The carbon fiber thread was treated before use by boiling with reflux in concentrated nitric acid for two hours as described in [29]. The reference electrode was a saturated calomel electrode (SCE) placed in the chamber of a working electrode. The kinetic curves of the anodic current were registered maintaining a fixed potential of the working electrode (300 $\mathrm{mV}$ vs SCE). The mediator, lactose and enzyme were added to the working electrode chamber, which was filled with the buffer solution. Charge $(\mathrm{Q}, \mathrm{C})$ passed during the electrolysis time $\left(t_{e p}, s\right)$ was calculated by integrating kinetic curves of current according to time, whereas $\mathrm{Q}$ normalized by Faraday constant $\left(F=9.648534 \times 10^{4} \mathrm{C} \mathrm{mol}^{-1}\right)$ gives the number of moles of electrons transferred during the electrolysis $(\mathrm{N}, \mathrm{mol})$. Assuming the stoichiometry of redox conversions of the mediator and lactose, $\mathrm{N}$ divided by $2(\mathrm{~N} / 2, \mathrm{~mol})$ was used to calculate the yield of the electrolysis (Y\%) and the total turnover numbers of the mediator and the enzyme $\left(T T N_{M}\right.$, and $T T N_{E}$, respectively). The average turnover number of the enzyme $\left(A T N_{E}\right)$ was calculated by normalizing $T T N_{E}$ to electrolysis time.

\section{RESULTS AND DISCUSSION}

\section{The parameters of PQQ-sGDH catalyzed lactose oxidation and the reactivity of the enzyme with electron transfer mediators}

The coupled ferricyanide reduction assay is a very convenient method to determine the parameters of the enzymatic reaction. The fast reaction of 
ferricyanide with a reduced form of the mediator the oxidized form of the mediator is generated. Considering the redox potentials of the investigated mediators and ferricyanide and a large excess of the ferricyanide concentration (about $1 \mathrm{mM}$ ) over the mediator concentration $(10 \mu \mathrm{M}$ or less) their bimolecular reaction equilibrium shifted to the formation of the oxidized form of the mediator.

In the case of both mediators their addition to the reaction mixture increased the rate of the ferricyanide reduction significantly (Fig. 2a). At the maximal investigated concentration of the mediator $(10 \mu \mathrm{M})$ the reaction rate dependence on the lactose concentration was studied. The rate increased when the lactose concentration in the reaction mixture was less than $2 \mathrm{mM}$, and at the concentrations of lactose above $2 \mathrm{mM}$ the inhibition of the enzyme reaction was observed (Fig. 2b). The ping-pong enzyme reaction scheme with enzyme inhibition by the substrate (Eqs. 1-3) was used to analyse the dependence of the rate on the mediator and substrate concentration and the constants of PQQ-sGDH catalyzed oxidation of lactose in the presence of the mediator AMB or MAZP were calculated (Table 1 ). $k_{o x}$ is the measure of the reactivity of the mediator with the reduced form of the enzyme, and the high values of this constant for both investigated mediators define them into a group of highly reactive compounds [5]. The similarity of the parameters of lactose oxidation in the case of both mediators confirms the ping-pong scheme of the enzyme action. It is important that the catalytic activity of the PQQ-sGDH decreases only slightly as the $\mathrm{pH}$ of the reaction mixture is shifted to $\mathrm{pH} 8.0-k_{\text {cat }}$ decreases by $35-48 \%$ and $k_{o x}$ by $20-30 \%$. At the same time the shift of $\mathrm{pH}$ of the reaction mixture allows one to significantly decrease the inhibition of PQQ-sGDH with the substrate - the value of $K_{i n}$ increases more than 3 times.

Table 1. The parameters of PQQ-sGDH catalyzed lactose oxidation in the presence of AMB or MAZP at $\mathrm{pH} 7.0$ and $\mathrm{pH} 8.0$

\begin{tabular}{ccc}
\hline Parameter & pH 7.0 & pH 8.0 \\
\hline AMB: & & \\
\hline$k_{c a^{\prime}} s^{-1}$ & $(1.6 \pm 0.1) \times 10^{3}$ & $(8.3 \pm 0.6) \times 10^{2}$ \\
\hline$K_{M^{\prime}} \mathrm{M}$ & $(1.8 \pm 0.1) \times 10^{-3}$ & $(1.4 \pm 0.6) \times 10^{-3}$ \\
\hline$K_{i n^{\prime}} \mathrm{M}$ & $(1.9 \pm 0.1) \times 10^{-2}$ & $(6.1 \pm 0.3) \times 10^{-2}$ \\
\hline$k_{o x^{\prime}} \mathrm{M}^{-1} \mathrm{~s}^{-1}$ & $(8.8 \pm 0.4) \times 10^{7}$ & $(7.0 \pm 0.4) \times 10^{7}$ \\
\hline $\mathrm{MAZP}:$ & & \\
\hline$k_{c a t^{\prime}} \mathrm{s}^{-1}$ & $(1.1 \pm 0.1) \times 10^{3}$ & $(7.1 \pm 0.6) \times 10^{2}$ \\
\hline$K_{M^{\prime}} \mathrm{M}$ & $(2.3 \pm 0.2) \times 10^{-3}$ & $(1.9 \pm 0.2) \times 10^{-3}$ \\
\hline$K_{i n^{\prime}} \mathrm{M}$ & $(1.6 \pm 0.1) \times 10^{-2}$ & $(5.5 \pm 0.5) \times 10^{-2}$ \\
\hline$k_{o x^{\prime}} \mathrm{M}^{-1} \mathrm{~s}^{-1}$ & $(5.7 \pm 0.4) \times 10^{7}$ & $(4.0 \pm 0.4) \times 10^{7}$ \\
\hline
\end{tabular}

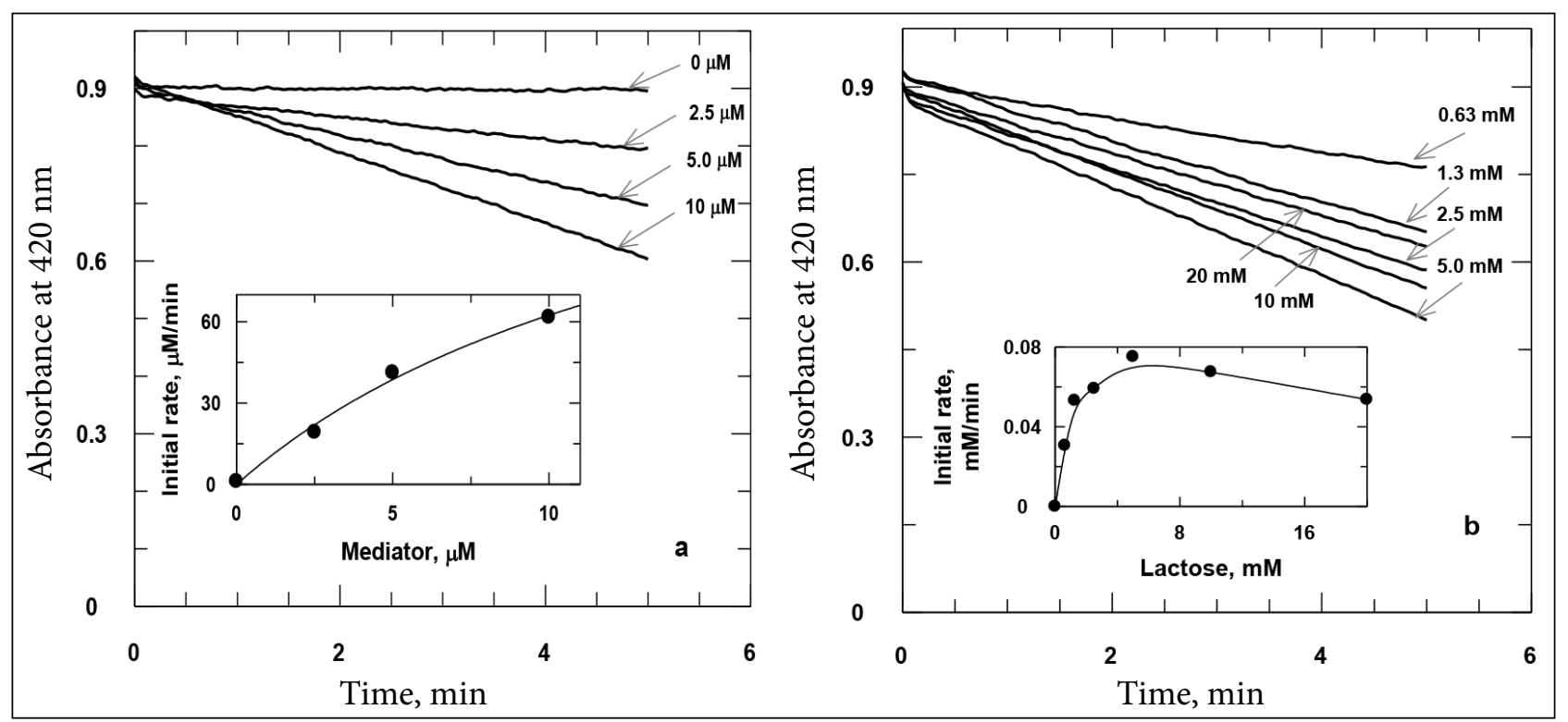

Fig. 2. The kinetic curves of ferricyanide absorbance decrease in the presence of PQQ-sGDH, glucose and various MAZP (a) or lactose (b) concentrations at $\mathrm{pH}$ 8.0. The inserted graph shows the dependence of the initial ferricyanide reduction rate on the added mediator or lactose concentration 


\section{Electroenzymatic lactose conversion to lactobionic acid}

The use of mediators for regeneration of the oxidized form of the PQQ-sGDH was investigated through the electrochemical oxidation of the mediator. During an electrochemical reaction, the anodic and cathodic compartments are separated by an electroconductive agarose gel which ensures the charge transfer between the compartments. The working electrode, on which the mediator is oxidized, is an anode, and the enzymatic reaction of substrate oxidation occurs in this electrode chamber. The counter electrode is the cathode, on which the secondary electrochemical reaction (usually the reduction of the proton resulting in the production of molecular hydrogen) occurs [29].

The kinetic curves of the anodic current for the mediator AMB at two different working electrode potentials are shown in Fig. 3. The increase of the current was observed after the addition of $\mathrm{AMB}$ to the chamber of the working electrode. The calculated number of moles of electrons passed during the electrolysis corresponded to the added amount of $\mathrm{AMB}$, considering one electron oxidation of $\mathrm{AMB}$ on the electrode. Lactose and PQQ-sGDH were added to the cell when almost all the AMB was oxidized. After the addition of the substrate and the enzyme, the increase in the current was registered. The oxidation of the lactose catalyzed by PQQ-sGDH proceeded according to the ping-pong scheme (Eqs. 1 and 2,

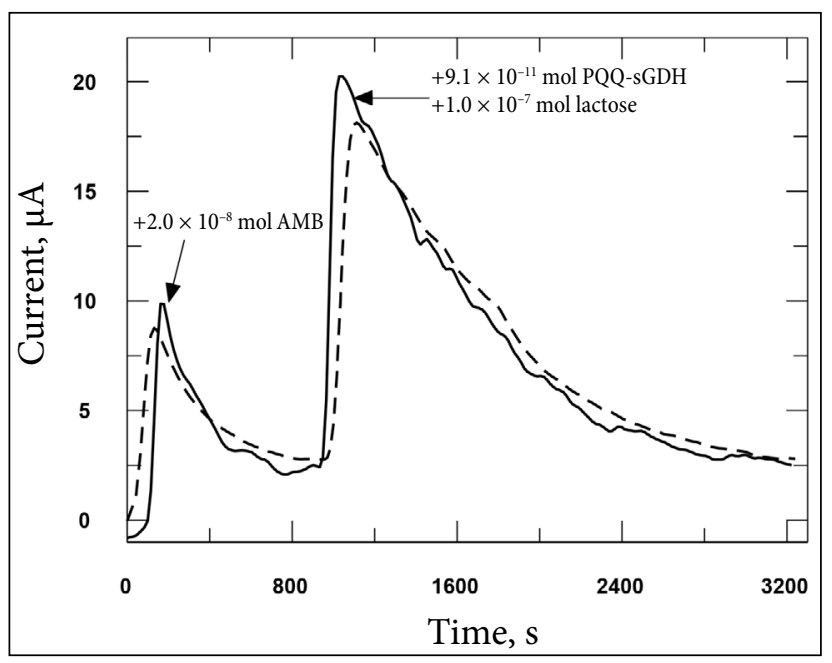

Fig. 3. $A M B$ chronoamperometric curves at $\mathrm{pH} 7.0$ and the electrode potential of $250 \mathrm{mV}$ vs SCE (solid line) or $300 \mathrm{mV}$ vs SCE (dashed line) inhibition reaction Eq. 3 was omitted as the used concentration of the lactose of $0.33 \mathrm{mM}$ was much lower than the inhibition constant). The reduced mediator formed during the reaction of enzyme oxidation was re-oxidized on the surface of the working electrode, resulting in the increase of the current. In the case of MAZP the chronoamperometric curves (Fig. 4) were different at the beginning of the process. The MAZP at its initial form is oxidized, so after the addition of this mediator to the working electrode chamber no current change was registered. After the addition of the lactose and enzyme the current increase and other changes in the current were the same as for the mediator AMB. The concentration of the substrate in the working electrode chamber decreased due to the consumption during electrolysis, consequently decreasing the rate of enzymatic reaction and the registered current of electrochemical mediator oxidation. After $32 \mathrm{~min}$ of electrolysis the conversion of substrate was $76 \%$ and higher (Table 2), and the maximum turnover numbers of the enzyme and of the mediator were 958 and 4.4, respectively. In the case of MAZP, the $T T N_{E}, T T N_{M}$ and $Y$ increase slightly at a higher electrode potential, ant the increase can be explained by the more efficient mediator oxidation on the electrode. In the case of AMB the $T T N_{E}, T T N_{M}$ and $Y$ decrease, and the decrease can be related to the second electron oxidation of $\mathrm{AMB}$ and the formation of an unstable product at a higher potential [23]. Electrode potentials of $250 \mathrm{mV}$ vs SCE and of

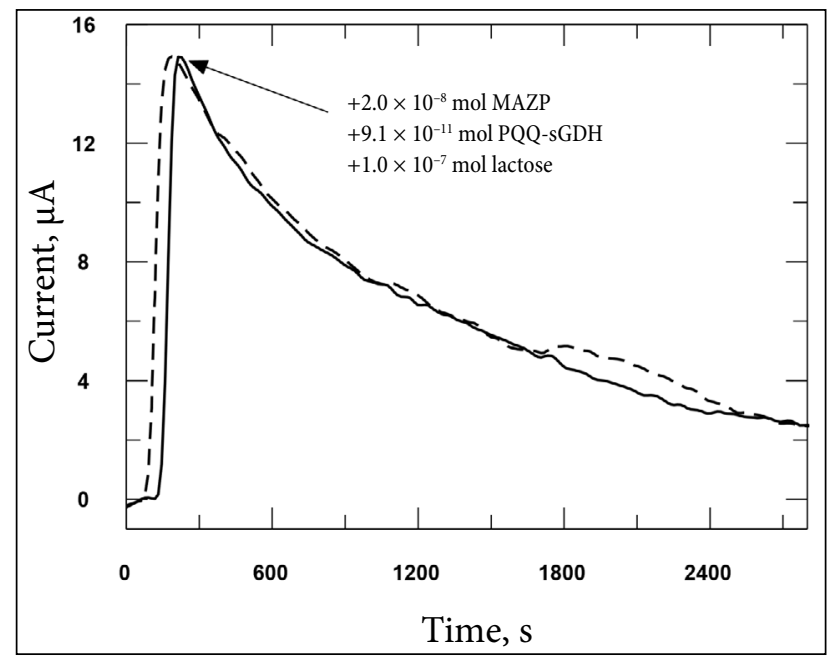

Fig. 4. MAZP chronoamperometric curves at $\mathrm{pH} 7.0$ and the electrode potential of $250 \mathrm{mV}$ vs SCE (solid line) or $300 \mathrm{mV}$ vs SCE (dashed line) 
Table 2. The numbers of moles of electrons transferred during the electrolysis (N/2), the total turnover numbers of the mediator and PQQ-SGDH (TTN ${ }_{M}$ and TTN $\left._{\mathrm{E}}\right)$ and the yield of the electrolysis $(\mathrm{Y})$ with various mediators and the working electrode potential at $\mathrm{pH} 7.0$, electrolysis time $32 \mathrm{~min}$, amounts of mediator, lactose and enzyme were $2.0 \times 10-8 \mathrm{~mol}, 1.0 \times 10-7 \mathrm{~mol}$ and $9.1 \times 10-11 \mathrm{~mol}$, respectively

\begin{tabular}{c|c|c|c|c|c}
\hline Mediator & Potential, $\mathbf{~} \mathbf{V}$ & $\mathbf{N} / \mathbf{2 , ~} \mathbf{m o l}$ & $\mathbf{T T N}_{\boldsymbol{E}}$ & $\boldsymbol{T T N}_{\boldsymbol{M}}$ & $\boldsymbol{Y}, \boldsymbol{\%}$ \\
\hline AMB & 250 & $8.7 \times 10^{-8}$ & 958 & 4.4 & 87 \\
\hline AMB & 300 & $8.2 \times 10^{-8}$ & 900 & 4.1 & 82 \\
\hline MAZP & 250 & $7.6 \times 10^{-8}$ & 830 & 3.7 & 76 \\
\hline MAZP & 300 & $8.7 \times 10^{-8}$ & 856 & 3.9 & 78 \\
\hline
\end{tabular}

$300 \mathrm{mV}$ vs SCE were chosen for further investigations with the mediators AMB and MAZP, respectively.

In attempt to increase the enzyme turnover number and the productivity of the system the electrolysis time was extended to 3-5 hours and the higher initial concentration of the substrate $-0.1 \mathrm{M}$ - was added to the reaction mixture. Two different electrodes were used as the working electrode and the electrolysis was performed in the buffer solution of two different $\mathrm{pH}-7.0$ and 8.0. To compare the results of different investigated cases the system productivity (as $\mathrm{mg}$ of lactobionic acid/mg of the enzyme) and the average enzyme turnover number during the electrolysis time $(1 / \mathrm{min})$ were calculated (Table 3 ). The maximum system productivity and the average turnover number of the enzyme were reached with the mediator AMB when the $\mathrm{pH}$ of the buffer solution was 8.0 and the carbon fiber electrode was used as the working electrode. For this case $6.8 \mathrm{mg}$ of the lactose oxidation product - lactobionic acid - was produced during the electrolysis time of $252 \mathrm{~min}$, and the total turnover number of the enzyme reached the value of $7.6 \times 10^{4}$. The results can be explained considering a much higher electrode surface area for the carbon fiber electrode, a lower inhibition of the enzyme by substrate at $\mathrm{pH} 8.0$, and a higher reactivity with the enzyme of AMB than of MAZP.

\section{CONCLUSIONS}

The investigated mediators showed a high reactivity with the PQQ-sGDH. The bimolecular rate constant of reactivity of the reduced form of the enzyme with MAZP or the radical cation of $\mathrm{AMB}$ was determined to be $(5.7 \pm 0.4) \times 10^{7} \mathrm{M}^{-1} \mathrm{~s}^{-1}$ or $(8.8 \pm 0.4) \times 10^{7} \mathrm{M}^{-1} \mathrm{~s}^{-1}$ at $\mathrm{pH} 7.0$, respectively. The enzyme catalyzed lactose oxidation parameters were determined using the mediators. The analysis of the parameters showed that the inhibition of the enzyme by substrate significantly decreased at $\mathrm{pH} 8.0$, whereas the catalytic activity of the enzyme decreased only slightly. The use of $A M B$ and MAZP for regeneration of the oxidized form of PQQ-sGDH was investigated by applying the elctrochemical oxidation of the mediator. The maximum electroenzymatic lactose bioconversion yield and PQQ-sGDH turnover number were reached when the buffer solution $\mathrm{pH}$ was 8.0

Table 3. Dependence of the average turnover number of the enzyme $\left(\operatorname{ATN}_{\mathrm{E}}\right)$ and of electroenzymatic system productivity $(\mathrm{P}, \mathrm{mg}$ of lactobionic acid/mg of PQQ-sGDH) on the mediator, medium $\mathrm{pH}$ and working electrode type

\begin{tabular}{cccccccccccc}
\hline Mediator & $\mathbf{p H}$ & Electrode & $\boldsymbol{t}_{\boldsymbol{e l}} \mathbf{m i n}$ & $\mathbf{N} / \mathbf{2}, \mathbf{~ m o l}$ & $\boldsymbol{T T N}_{\boldsymbol{E}}$ & $\boldsymbol{T T N}_{\boldsymbol{M}}$ & $\boldsymbol{A T N}_{\boldsymbol{E}}$ & $\boldsymbol{P}$ \\
\hline AMB & 8.0 & C fiber & 252 & $2.1 \times 10^{-5}$ & $7.6 \times 10^{4}$ & 99 & 301 & 252 \\
\hline AMB & 7.0 & C fiber & 278 & $1.8 \times 10^{-5}$ & $6.9 \times 10^{4}$ & 90 & 248 & 237 \\
\hline MAZP & 8.0 & C fiber & 265 & $1.4 \times 10^{-5}$ & $5.2 \times 10^{4}$ & 65 & 173 & 178 \\
\hline MAZP & 7.0 & C fiber & 283 & $1.2 \times 10^{-5}$ & $4.4 \times 10^{4}$ & 58 & 157 & 152 \\
\hline AMB & 8.0 & Pt wire & 322 & $6.3 \times 10^{-6}$ & $6.9 \times 10^{4}$ & 90 & 213 & 233 \\
\hline AMB & 7.0 & Pt wire & 282 & $4.7 \times 10^{-6}$ & $5.2 \times 10^{4}$ & 67 & 183 & 178 \\
\hline MAZP & 8.0 & Pt wire & 355 & $3.2 \times 10^{-6}$ & $3.6 \times 10^{4}$ & 46 & 100 & 122 \\
\hline MAZP & 7.0 & Pt wire & 187 & $1.7 \times 10^{-6}$ & $1.8 \times 10^{4}$ & 24 & 98 & 67 \\
\hline
\end{tabular}


and $\mathrm{AMB}$ was used as an electron acceptor, which was oxidized on a carbon fiber electrode of a large surface area.

Received 6 June 2019

Accepted 17 June 2019

\section{References}

1. N. R. Mohamad, N. H. C. Marzuki, N. A. Buang, F. Huyop, R. A. Wahab, Biotechnol. Biotechnol. Equip., 29(2), 205 (2015).

2. S. W. May, Curr. Opin. Biotechnol., 10(4), 370 (1999).

3. M. Hall, A. S. Bommarius, Chem. Rev., 111, 4088 (2011).

4. L. Marcinkevičienè, J.Stankevičiūtè, I. Bachmatova, R. Vidžiūnaite, A. Chaleckaja, R. Meškys, Chemija, 23(3), 223 (2012).

5. L. Tetianec, I. Bratkovskaja, J. Kulys, V. Casaite, R. Meskys, Appl. Biochem. Biotechnol., 163, 404 (2011).

6. K. Matsushita, H. Toyama, M. Yamada, O. Adachi, Appl. Microbiol. Biotechnol., 58, 13 (2002).

7. J. A. Duine, J. Biosci. Bioeng., 88, 231 (1999).

8. C. Anthony, Biochem. J., 320, 697 (1996).

9. K. Matsushita, E. Shinagawa, O. Adachi, M. Ameyama, Biochemistry, 28, 6276 (1989).

10. A. Oubrie, H. J. Rozeboom, K. H. Kalk, A. J. Olsthoorn, J. A. Duine, B. W. Dijkstra, EMBO J., 18(19), 5187 (1999).

11. A. J. Olsthoorn, T. Otsuki, J. A. Duine, Eur. J. Biochem., 255(1), 255 (1998).

12. A. Oubrie, H. J. Rozeboom, K. H. Kalk, J. A. Duine, B. W. Dijkstra, J. Mol. Biol., 289(2), 319 (1999).

13. A. Oubrie, H. J. Rozeboom, B. W. Dijkstra, Proc. Natl. Acad. Sci. USA, 96, 11787 (1999).

14. J. Okuda, K. Sode, Biochem. Biophys. Res. Commun, 314(3), 793 (2004).

15. S. Igarashi, J. Okuda, K. Ikebukuro, K. Sode, Arch. Biochem. Biophys., 428(1), 52 (2004).

16. M. Stredanský, R. Monošík, V. Mastihuba, E. Šturdík, Appl. Biochem. Biotechnol., 171(4), 1032 (2013).

17. F. Durand, C. Stines-Chaumeil, V. Flexer, I. André, N. Mano, Biochem. Biophys. Res. Commun, 402(4), 750 (2010).

18. P. Dokter, J. Frank, J. A. Duine, Biochem. J., 239, 163 (1986).

19. M. Nordkvist, P. M. Nielsen, J. Villadsen, Biotechnol. Bioeng., 97(4), 694 (2007).

20. S. Alonso, M. Rendueles, M. Díaz, Biotechnol. Adv., 31(8), 1275 (2013).
21. L. Tetianec, A. Chaleckaja, J. Kulys, et al., Process Biochem., 54, 41 (2017).

22. A. Safavi, O. Moradlou, M. Saadatifar, Electroanalysis, 22(10), 1072 (2010).

23. J. Kulys, T. Buch-Rasmussen, K. Bechgaard, et al., J. Mol. Catal., 91(3), 407 (1994).

24. C. Kohlmann, W. Markle, S. Lutz, J. Mol. Catal. B: Enzym., 51, 57 (2008).

25. A. J. Olsthoorn, J. A. Duine, Arch. Biochem. Biophys., 336(1), 42 (1996).

26. J. Kulys, L. Tetianec, Biosens. Bioelectron., 21, 152 (2005).

27. J. Kulys, L. Tetianec, I. Bratkovskaja, Biotechnol. J., 5, 822 (2010).

28. R. W. Estabrook, J. Biol. Chem., 236, 3051 (1961).

29. C. Bourdillon, R. Lortie, J. M. Laval, Biotechnol. Bioeng., 31(6), 553 (1988).

Greta Vaitkutė, Irina Bratkovskaja, Vida Časaitė, Jonita Stankevičiūtė, Rolandas Meškys, Lidija Tetianec

\section{ELEKTRONŲ PERNAŠOS MEDIATORIAI TIRPIOS, NUO PQQ PRIKLAUSOMOS, GLIUKOZĖS DEHIDROGENAZĖS KATALIZUOJAMAI LAKTOZĖS OKSIDACIJOS REAKCIJAI}

Santrauka

Nuo PQQ priklausoma tirpi gliukozės dehidrogenaze (PQQ-sGDH) pasižymi geru kataliziniu aktyvumu, atsparumu deguoniui bei plačiu specifiškumu sacharidiniams substratams. Dèl potencialiai naudingų savybių šis fermentas gali būti panaudojamas daugybèje sričių, iskaitant sacharidų biojutiklių konstravimą bei bioreaktoriuose naudingų junginiu sintetinimui biokonversijos reakcijose. Efektyviam fermento pritaikymui bei veikimui yra reikalingi geri elektronu akceptoriai, todèl šio darbo tikslas buvo ištirti dirbtinių elektronų pernašos mediatorių reaktingumą ir pritaikymą PQQ-sGDH katalizuojamose reakcijose. 1-(N,N-dimetilamino)-4-(4-morfolino)benzenas (AMB) ir $\mathrm{N}, \mathrm{N}^{\prime}$-dimetil-4,4'-azopiridino metil sulfatas (MAZP) šiame darbe naudoti kaip mediatoriai. Nustatytos AMB ir MAZP reaktingumo su PQQ-sGDH konstantos ir PQQ-sGDH katalizuojamos laktozès oksidacijos parametrai. Oksiduotos PQQ-sGDH formos regeneracijos schema buvo tirta taikant elektrocheminę mediatoriaus oksidaciją. Didžiausia elektroenzimatinès laktozès biokonversijos išeiga ir didžiausias vidutinis PQQ-sGDH virsmų skaičius pasiekiamas esant $\mathrm{pH}$ 8,0, kai elektronų pernašos mediatorius AMB oksiduojamas ant didelio ploto anglies pluošto elektrodo. 